\title{
Marine photosynthetic eukaryotes in polar systems: Unveiling phytoplankton diversity and composition in Antarctic waters
}

\author{
Eucariotas fotosintéticos marinos en sistemas polares: \\ Descubriendo la diversidad y composición del fitoplancton en aguas antárticas
}

\author{
RODRIGO DE LA IGLESIA $1,3,{ }^{*} \&$ NICOLE TREFAULT1, 2 \\ ${ }^{1}$ Departamento de Genética Molecular y Microbiología, Facultad de Ciencias Biológicas, Pontificia Universidad Católica de \\ Chile, Portugal 49, Santiago, Chile \\ ${ }^{2}$ Centro de Genómica y Bioinformática e Instituto de Biotecnología, Universidad Mayor, Camino La Pirámide 5750, \\ Huechuraba, Santiago, Chile \\ ${ }^{3}$ Center for Advanced Studies in Ecology and Biodiversity, CASEB, Pontificia Universidad Católica de Chile, Santiago, Chile \\ ${ }^{*}$ Corresponding author: rdelaiglesia@bio.puc.cl
}

\begin{abstract}
Antarctic waters are a particular marine environment mainly due to the strong seasonal variations that various parameters are subject to, like light availability and temperature. As in all oceanographic regions, food webs are sustained by photosynthetic microorganisms, which in the case of Antarctic environments seem to be strongly dominated by its eukaryote component. Assessing the ecological role of photosynthetic microbial eukaryotes requires a basic knowledge of their diversity and community composition. This review integrates the available information regarding this component of Antarctic phytoplankton as a way to unveil its diversity and how they respond to the strong changes that occur in this environment. Although several studies indicate the presence of a highly endemic biota in Antarctica, data sets on marine photosynthetic eukaryotes diversity suggests that endemism may be strongly influenced by the low coverage that Antarctic marine areas have been subjected. Moreover, most studies demonstrate that climate change is occurring faster than expected, especially in the Antarctic Peninsula and that this could result in a significant loss of global microbial biodiversity. The changes that eukaryote phytoplankton experience due to this phenomenon may have strong repercussion on the food webs in the Southern Ocean. The knowledge of both the diversity and variation of marine eukaryote phytoplankton in Antarctic waters is crucial for the proper understanding and predictability regarding how these environments can respond to a changing ocean.
\end{abstract}

Key words: Antarctic, biodiversity, photosynthetic eukaryotes, phytoplankton.

\section{RESUMEN}

Las aguas antárticas son un ambiente marino peculiar debido principalmente a las fuertes variaciones estacionales a las que están sujetos varios parámetros, como disponibilidad de luz y temperatura. Al igual que en todas las regiones oceanográficas, las tramas tróficas se encuentran sustentadas por microorganismos fotosintéticos, que en el caso de ambientes antárticos parecen estar fuertemente dominados por su componente eucarionte. Este trabajo integra la información disponible respecto a este componente del fitoplancton antártico como una forma de descubrir su diversidad y cómo estos organismos responden a las variaciones a las que se ven sujetos en estos ambientes. Aunque varios estudios indican la presencia de una biota altamente endémica en la Antártica, el conjunto de datos sobre la diversidad de eucariontes marinos fotosintéticos sugiere que este endemismo puede estar fuertemente influenciado por la baja cobertura a la que las áreas marinas antárticas han sido sometidas. Por otro lado, la mayoría de los estudios demuestran que el cambio climático está ocurriendo más rápido de lo esperado, especialmente en la Península Antártica y que esto podría resultar en una pérdida significativa de biodiversidad microbiana global. Además, los cambios que el fitoplancton eucarionte experimente debido a este fenómeno pueden tener fuertes repercusiones en las cadenas tróficas en el océano Austral. El conocimiento tanto de la diversidad como la variación de los microorganismos marinos eucariontes en aguas antárticas es información crucial para la correcta comprensión y capacidad de predicción respecto a cómo estos ambientes pueden responder a los cambios a los que está sujeto.

Palabras clave: Antártica, biodiversidad, eucariontes fotosintéticos, fitoplancton. 


\section{INTRODUCTION}

Polar marine systems are unique marine environments, whose differences with other habitats range from temperature to light intensity, including high nutrients but low chlorophyll concentration. However, one of the most important features is the presence of sea ice. Polar microbial communities are greatly affected by sea ice, since it limit the light penetration into the upper ocean and thus provide unique sea-surface habitats. These habitats support a diverse and dynamic assemblage of microorganisms, including eukaryote and bacterial phytoplankton (Hollibaugh et al. 2007). Particularly for Antarctic waters, it is proposed that the isolation of the organisms over the last $100 \mathrm{Myr}$ in this extreme environment, have determined the presence of a highly endemic biota, with diversity and abundance of taxonomic groups completely different from elsewhere in the world (Rogers 2007). However, these observations have been done mainly with macroscopic organisms and the endemism of microbial communities is actually subject of debate.

Both phototrophic and heterotrophic microbial eukaryotes are ubiquitous in extreme cold-water environments, where they are- as in all marine environments- central in the production and utilization of energy and the cycling of elements. However, assessing the ecological role of photosynthetic microbial eukaryotes requires a basic knowledge of species abundances and in situ composition. In high latitude areas, technical and economic constraints have hindered in gaining a more comprehensive view of diversity and composition of several microbial groups. In the case of Antarctica, due to the wide distance from populated areas than any other part of the world and extreme climate conditions, access during the whole year is often difficult, leading to an overall picture where diversity and community structure of microbial photosynthetic eukaryotes is much more limited than in other marine systems.

In this work, we integrate the available information on diversity of marine photosynthetic eukaryotes in Antarctic waters, in an effort to unveil how they respond to the strong changes that occur in these environments.

\section{The Southern Ocean}

Covering approximately $10 \%$ of the world's oceans, the Southern Ocean is a significant component of the global marine biome (Constable \& Nicol 2003, Nicol et al. 2008), and can be considered as a heterogeneous system determined by a strong seasonality due to long dark winters with minimal primary productivity (Manganelli et al. 2009). Nevertheless, the Southern Ocean exerts a preponderant control on atmospheric $\mathrm{CO}_{2}$ sequestration and doing so, plays a critical role in the global carbon cycle (Denman et al. 2007), hence the need of understanding the role of the inhabiting biota in the regulation of carbon fixation and cycling.

The pelagic ecosystem of the Southern Ocean can be defined by distinct provinces that include the polar front zone, the permanently open ocean zone, the sea-ice zone, and the coastal and continental shelf (Arrigo \& Thomas 2004, Nicol et al. 2008). During spring and summer, the coastal and ice edge waters experience intense blooms -mainly of diatoms and of the haptophyte Phaeocystis - that support a rich food web via zooplankton and krill to penguins and whales. In the other hand, the open ocean is one of the largest oceanographic areas with a regime of high-nutrients lowchlorophyll (HNLC), that is characterized by a low primary productivity, limited by iron (Manganelli et al. 2009).

Besides, polynyas, i.e. limited areas of persistently open waters that result from a variety of physical processes, provide special habitats, that are completely different from areas that are ice covered during great part of the year (Hollibaugh et al. 2007). Polynyas can act as nutrient reservoirs that allow productivity at high rates (Arrigo \& van Dijken 2003). Consequently, several studies show that microbes in the polynya are more active than their counterparts under the adjacent ice cover, and that there is a small overlap between the phytoplankton species found in adjacent sea ice and open waters (Lovejoy et al. 2002, Hollibaugh et al. 2007, Baldi et al. 2011).

\section{Marine microbial eukaryotes and photosynthesis}

Marine photosynthetic eukaryotes are a diverse and complex group of key organisms inhabiting a variety of environments where 
light can penetrate just enough to sustain life. Due to their ability to use light and inorganic carbon to produce organic molecules, they are considered the base of the energy fluxes in the ocean, as well as their bacterial counterpart (cyanobacteria). In general terms, marine photosynthetic organisms are responsible for about half of the photosynthetic activity of the planet (Field et al. 1998), even when they account for just $0.2 \%$ of the photosynthetic biomass (Behrenfeld \& Falkowski 1997, Falkowski et al. 1998). In the Southern Ocean it has been estimated that photosynthesis by eukaryote phytoplankton is responsible for up to $15 \%$ of global marine primary production (Huntley et al. 1991).

The species that compose the phytoplankton can be classified through different approaches as microscopy, pigment composition or molecular markers involving mostly $16 \mathrm{~S} / 18 \mathrm{~S}$ rRNA genes. Besides, a simple and useful way to classify them is by categorizing based on cell size. According to this, phytoplankton can be divided into: micro-phytoplankton (200-20 $\mu \mathrm{m}$ diameter), nano-phytoplankton (20-2 $\mu \mathrm{m}$ diameter) and pico-phytoplankton (2-0.2 $\mu \mathrm{m}$ diameter) (Sieburth 1978). The study of the phytoplanktonic community in terms of size and structure is relevant because its relative dominance has to be taken into account in the analysis of several processes like: the fate of phytoplankton production, its flow through grazing, sinking and export productions, and in the evaluation of carbon fluxes throughout the water column (Rodríguez et al. 2002).

\section{Diversity of eukaryotic phytoplankton in Antarc- tic waters}

Traditional microscopic approaches for estimating diversity and population structure of microbial eukaryote assemblages have contributed to our current understanding of species biogeography, microbial food web structure, and biogeochemical processes in the Southern Ocean (Wright et al. 1996, TorresZambrano \& Tapia 1998, Riaux-Gobin et al. 2003). Principally, for those species generally greater than $20 \mu \mathrm{m}$ in size and with distinctives and unambiguous morphological features, such as frustules, loricae, or skeletons, microscopybased diversity analysis have been extremely useful (Gast et al. 2004). This is the case of large diatoms and dinoflagellates, tintinnid ciliates, and choanoflagellates. However, this approach is not suitable to characterize the diversity of a significant number of species that have morphologically less distinctive traits (Gast et al., 2004) or smaller size.

The application of the so called "molecular techniques" in the study of eukaryote phytoplankton community structures has allowed us to obtain a more detailed resolution compared to this classical approach. During the past fifteen years, the application of these methodologies has highly expanded our knowledge on bacterial and archeal diversity, but its application on the eukaryote component remains only a fraction of the large number of studies devoted to the former groups. This is even greater when only Antarctic regions are considered. Although molecular methods today offer new perspectives for studying phytoplankton biogeography, activity, biological interactions, and population control mechanisms (Massana 2011), what seems to be the next advance in eukaryote microbial ecology is the application of integrated methodologies and strategies, like the use of flow cytometry together with cell sorting and clone libraries or high throughput sequencing, i.e., 454, Illumina/Solexa, ABI/SOLiD (see for example: Zehr et al. 2008, Lepère et al. 2011). At this moment, several ongoing projects and initiatives are using these integrated approaches in distinct geographical areas of Antarctica, which will certainly improve our understanding of the taxonomical and functional diversity of microbial photosynthetic eukaryotes in this environment.

For several years, a concept of short, low-diversity polar food chains was generally assumed. However, based on molecular techniques and a genetic scope of microbial eukaryote diversity, scientific research conducted over the past two decades has shown that this concept is overly simplistic (Smetacek $\&$ Nicol 2005). Altogether, data indicate that although comparatively few species do provide the bulk of food to polar marine predators, the planktonic base is very similar and equivalent in terms of their phylogenetic diversity to the planktonic base in other regions, like temperate zones (Smetacek \& Nicol 2005). Altogether, these studies have suggested that pelagic food webs are broadly similar across all latitudes 
in terms of both their structure and function (López-García et al. 2001a, Smetacek et al. 2004).

The micro-eukaryotic diversity of Eastern Antarctic coastal waters (Prydz Bay, at Davis station-Australia, Fig. 1A) assessed through molecular analysis, revealed several different phylotypes, belonging to the Dinophyceae, Stramenopiles, Choanoflagellidae, Ciliophora, Cercozoa and Metazoa groups. The group that dominates is the dinoflagellates. The high diversity observed can be an indicator of the relevant role this organisms have in coastal areas of Antarctica just before ice breakup and between the development of phytoplanktonic blooms (Piquet et al. 2008). In addition, microscopic data on the diversity of the microeukaryotic community gathered in another Antarctic coastal site (Fig. 1B, Terre Adélie), from a lead and small polynyas directly under the ice, revealed moderate diversity indexes, where diatoms - particularly pennate- were dominant (Riaux-Gobin et al. 2003). However, it should be noted that diversity studies based on microscopy and molecular techniques are not comparable because of the high resolution difference that underlie these methodologies. Similarly, data on marine micro-eukaryotic diversity, applying different molecular methods with a varying resolution level, are not always equivalent. Accordingly, and keeping resolution differences in mind, diversity data suggest that the micro-eukaryotic community from Prydz Bay had a similar, but slightly higher diversity as compared to other diversity studies (Piquet et al. 2008). Extrapolation of these results to all Antarctic waters, however, requires a much larger number of studies using approaches and methodologies that could be intrinsically comparable.

In the case of the nano-eukaryotes, flagellates representatives are one of the classes more abundant in Antarctic waters (Weber \& El-Sayed 1987), being Phaeocystis sp. one of the most abundant and studied representatives. In part, this is due to one of the distinctive characteristics of Phaeocystis, its ability to form dense colonies that float in the seawater. These colonies are composed by hundreds of cell forming a biofilm-like structure, with a matrix of exopolysaccharide agglomerating the cells (Piquet et al. 2008). Similarly, another group of nano-phytoplankton typically characteristic of Antarctic waters is the autotrophic flagellate Cryptomonas. It has been detected as a dominant component in regions of the Gerlache Strait (Rodríguez et al. 2002, Fig. 1C), Weddell Sea (Mura et al. 1995, Fig. 1D) and Bransfield Strait (Kang \& Lee 1995, Fig. 1E).

Based on data collected in different sites in Prydz Bay during the spring bloom, and in other data previously published (Savage 1930, Sieburth 1960) Davidson \& Marchant (1992) postulate that autotrophic organisms are affected in its growth by Phaeocystis blooms during the Antarctic spring bloom. However, this is not always the case, since during a spring Phaeocystis sp. bloom in eastern McMurdo Sound (Fig. 1F), was shown that phytoplankton biomass was high and although dominated by colonial and single celled Phaeocystis, other phytoplankton taxa, including diatoms and photosynthetic dinoflagellates, co-occurred (Stoecker et al. 1995). Similarly, Fryxell \& Kendrick (1988) found a positive correlation between Phaeocystis and total diatom abundance in the vicinity of the Weddell Sea (Fig. 1D) ice edge during the austral spring. These contradictory studies just highlight the urgent need of conduct more research associated with the establishment and development of Antarctic spring blooms, to fully understand the community behavior during these complex phenomena.

Antarctic pico-phytoplankton is dominated by Prasinophytes and Prymnesiophytes (Weber \& El-Sayed 1987, Diez et al. 2001, Agawing et al. 2002), with a bacterial component that seems to be scarce (Agawing et al. 2002, Doolittle et al. 2008). The work of López-García et al. (2001a, 2001b, Fig. 1C, 1G, 1H and 1I) was one of the first to report new groups of uncultivated picoeukaryotes in waters of the Antarctic Polar Front. Although it was not a study focused on photosynthetic eukaryotes, because the samples were taken from deep waters, through $18 \mathrm{~S}$ rRNA gene sequences analysis, they detected the presence of three new lineages of marine eukaryotes: group I and II alveolates and marine stramenopiles. Since then these groups of eukaryote microorganisms have been reported throughout the world's seas and oceans, opening a new window for study the diversity of photosynthetic eukaryotes in this environment. A genetic survey of picoplankton performed by Díez et al. (2001, 


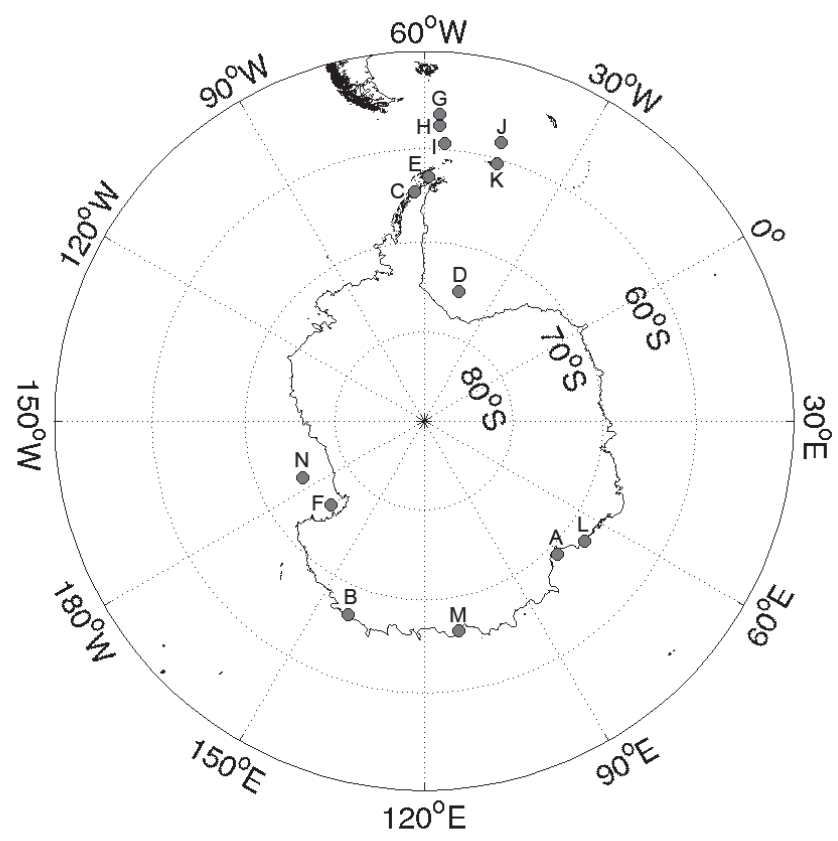

Fig. 1: Geographic location of the different sampling areas subjected to eukaryote phytoplankton diversity and composition analysis and summarized in this review. (A) Prydz Bay, (B) Terre Adélie, (C) Gerlache Strait, (D) Weddell Sea, (E) Bransfield Strait, (F) McMurdo Sound, (G, H and I) sampling sites López-García et al. (2001a, 2001b), (J and K) sampling sites Díez et al. (2001), (L) Mawson Station, (M) Casey Station, (N) Ross Sea.

Ubicación geográfica de las distintas zonas de muestreo en las que se han llevado a cabo análisis de diversidad y composición de fitoplancton eucarionte y resumidas en esta revisión. (A) Bahía Prydz, (B) Terre Adélie, (C) Estrecho Gerlache, (D) Mar de Weddell, (E) Estrecho Bransfield, (F) McMurdo Sound, (G, H and I) sitios de muestreo en López-García et al. (2001a, 2001b), (J and K) sitios de muestreo en Díez et al. (2001), (L) Estación Mawson, (M) Estación Casey, (N) Mar de Ross.

Figs. 1J-K) discovered a wide range of diversity of pico-phytoplankton, with representatives of the Prasinophytes, Prymnesiophytes, diatoms, Pelagophytes, Glaucocystophytes, Dictyochales, Bolidophytes and many novel stramenopiles, with many of the detected species having been described in other marine environments. The diversity reported by Díez et al. (2001) correlates with the report by Wright et al. (2009) in a transect between Mawson and Casey Bases (Fig. 1L-M), almost in the opposite point where Díez et al. performed the molecular analysis. By HPLC analysis of pigment profiles from the pico-phytoplanktonic fraction, they detected the same taxonomic groups as dominant components of this fraction. Putting it into perspective, all this data sets suggests that endemism may be only an artifact produced by the low coverage that Antarctic marine areas have been subjected to until now.
What can we expect about eukaryote phytoplankton composition in Antarctic waters?

The genetic composition and distribution analysis of microbial eukaryotes within different microhabitats (seawater, melt water or slush on sea-ice floes, and ice) in the Ross Sea (Fig. 1N), have shown that the composition of the communities tend to be more similar depending on the microhabitat than on the geographic location were the sample was collected. That is, those microbial eukaryotic communities from seawater were more similar between them than with the community inhabiting sea-ice in the same specific location, indicating a strong effect of microenvironments over the species composition of the assemblages (Gast et al. 2004).

As mentioned before, variation of physical parameters, like light availability and temperature can be drastic in Antarctic 
waters, having a direct effect on phytoplankton diversity and composition. Although analysis of the effect of these parameters using a size fractionation approach, mostly based on chlorophyll a or on DNA libraries, has been widely used (Weber \& El-Sayed 1987, Stoecker \& Moissan 1995, Wright et al. 1996, Fiala et al. 1998, Agawin et al. 2002, Doolittle et al. 2008, Piquet et al. 2008, Wright et al. 2009), the results obtained are often contradictory or non-conclusive, indicating that more data is necessary to fulfill a general picture in this topic. To our knowledge there is no study were the complete size-fractions (micro- nano- and pico-phytoplankton) have been analyzed at the same time using molecular tools.

What has been established in general terms, is that during summer time (i.e. high solar radiation) the micro-phytoplankton component dominates the community. While during winter nano- and pico-phytoplankton dominate the phytoplankton in terms of abundance (Fiala et al. 1998, Doolittle et al. 2008). These observations indicate that this size-fraction may be a critical element of the food web of the Southern Ocean, representing a seasonally stable biomass that is important for maintaining the food web. However, evaluating that type of conclusions is not easy because there are a greater number of studies relating to larger-size phytoplankton and there is not enough data available on the abundance of pico-phytoplankton during austral winter (Doolittle et al. 2008). In this sense, Doolittle et al. (2008) analyze the pico-phytoplankton community during the Austral winter in a transect covering from the Southern Antarctic Circumpolar Current Front (SACCF) to the Subtropical Front. They found that pico-eukaryotes were in fact the only pico-phytoplankton group in the coldest, southernmost sampling locations during winter. Considering that the SACCF is the largest ocean current connecting the Atlantic, Pacific and Indian Ocean basins, keeping the warm ocean waters away from Antarctica, it is remarkable that this underrepresented group of marine microorganisms supports the whole food web to higher trophic levels during the winter in an important part of the ocean.

Change in size-structure due to physical forces has also been addressed in Antarctic waters. Rodríguez et al. (2002) found changes in the phytoplankton composition associated to differences in the structure of the water bodies between the Bellingshausen Sea and Bransfield Strait. The first, which has a cold layer product of ice melting, is dominated by micro-phytoplankton- particularly Phaeocystis colonies- while the second, with a warmer surface layer, presents a phytoplanktonic community dominated by Cryptomonas and other flagellates; the central body water was dominated by diatoms. Their results suggest the alternation between a micro-phytoplankton dominated community in turbulent areas with flagellate blooms (Phaeocystis and Cryptomonas) during particular stratified conditions. These data might have relevant implications on climate change models that predict variations in the phytoplanktonic composition and the impact that these changes have on higher food webs (Montes-Hugo et al. 2009).

\section{Antarctica, the Southern Ocean and global change}

Most studies demonstrate that climate change is occurring faster than expected, especially in Polar Regions (Holland \& Bitz 2003). Accordingly, it has been reported that the Antarctic Peninsula is one of the most rapidly warming regions on Earth (Doran et al. 2002, Turner et al. 2005). In this context, the cold and remote Southern Ocean and Antarctica are threatened environments that require special protection and care, as revealed by several international protocols and protection initiatives. However, the fact that global change -including climate change- could result in a significant loss of global microbial biodiversity, and that numerous studies aimed to establishing that the diversity of certain groups of photosynthetic microorganisms are yet to be discovered, force to increase the growing concern for this environment.

One of the important consequences that climate change cause is changes on sealevel. In fact, during the past 100 years an increase in temperature of circa $0.8^{\circ} \mathrm{C}$ has been detected globally and, as the same time, sea-level rises about $20 \mathrm{~cm}$ (Solomon et al. 2007). The high sensitivity that Antarctic sea ice has as a component of climate at a global scale could results in a high positive feedback over the global climate system, by acting as an amplifier of the effect (Budd 1991), and thus, 
affecting the balance of energy due to changes in relevant processes, like albedo or enthalpy fluxes (Simmonds \& Wu 1993, Pezza et al. 2011).

Moreover, the yearly recurring spring time stratospheric ozone depletion enhances surface-incident biologically effective UV-B (280-315 $\mathrm{nm}$ ) radiation in Antarctica, so it is logical to ask questions regarding the adaptation of certain groups of photosynthetic microorganisms to UV radiation increases. Minicosms experiments, where natural Antarctic marine microbial eukaryote communities were incubated under different irradiation regimes, did not show major or consequent variations in community composition between different experiments, suggesting that a significant contribution of natural UV irradiance towards (at least) the micro-eukaryotic community composition is not important (Piquet et al. 2008). However, and in a somehow opposite way, Neale et al. (2001) observe a variable but generally high sensitivity of natural phytoplankton assemblages to UV radiations, measured by biological weighting functions and exposure response curves for inhibition of photosynthesis by UV.

At this point, it is important to note that without baseline data, predictive models of global changes cannot be constructed. Thus, exploring and understanding microbial photosynthetic eukaryote diversity and composition in Antarctic waters and the Southern Ocean will certainly improve our ability to predict how phytoplankton will react to a changing world.

\section{Concluding remarks}

Phytoplankton is a key element in the highly complex system that Antarctic waters represent, and thus, understanding its diversity and community structure or composition is critical, not only to biological oceanography, but also to understanding the activities and ecosystem functioning in this extreme cold habitat. The fact that many new species (and their ecology) are yet to be described all around the oceans -including polar systems and Antarctic waters for sure- it is fundamental to point out the importance of revealing diversity of eukaryote phytoplankton as a starting point. In this sense, many important questions concerning both the taxonomical and functional diversity of Antarctic marine phytoplankton can be addressed, such as: (1) How does microbial photosynthetic eukaryote diversity impact energy and nutrient cycling within Antarctic microbial communities? (2) Are the phylogenetic and genomic diversity of Antarctic phytoplankton species similar to other polar systems? (3) Is, indeed, the diversity of polar systems similar or different to that of other areas in the Ocean? (4) Which adaptive mechanisms enable single cells of eukaryote phytoplankton or their populations to resist major photosynthetic periods without light? And, are both mechanisms similar or different? And finally, (5) how do eukaryote phytoplankton communities respond to effects of climate or global changes?

ACKNOWLEDGMENTS: We are thankful of the invitation to participate in this special feature of the Revista Chilena de Historia Natural. We also thank Daniella Spooner for kindly revising and correcting our English and to $\mathrm{AK}$ and VK for his patience during the writing of this manuscript. We also thank two anonymous reviewers that help us to improve the quality of the manuscript and to Cristián Henríquez for helping us with the figure. This work has been funded by Instituto Antártico Chileno (INACH) Grant T16-10.

\section{LITERATURE CITED}

AGAWIN N, S AGUSTI \& C DUARTE (2002) Abundance of Antarctic picophytoplankton and their response to light and nutrient manipulation. Aquatic Microbial Ecology 29: 161-172.

ARRIGO KR \& DN THOMAS (2004) Large-scale importance of sea ice biology in the Southern ocean. Antarctic Science 16: 471-486.

ARRIGO KR \& GL VAN DIJKEN (2003) Phytoplankton dynamics within 37 Antarctic coastal polynya systems. Journal of Geophysical Research 108: 3271.

BALDI F, C FACCA, D MARCHETTO, TNM NGUYEN \& R SPURIO (2011) Diatom quantification and their distribution with salinity brines in coastal sediments of terra nova bay (Antarctica). Marine Environmental Research 71: 304-311.

BEHRENFELD MJ \& PG FALKOWSKI (1997) Photosynthetic rates derived from satellitebased chlorophyll concentration. Limnology and Oceanography 42: 1-20.

BUDD WF (1991) Antarctica and global change. Climatic Change 18: 271-299

CONSTABLE AJ, S NICOL \& PG STRUTTON (2003) Southern Ocean productivity in relation to spatial and temporal variation in the physical environment. Journal of Geophysical Research 108: 8079.

DAVISON AT \& HJ MARCHANT (1992) Protist abundance and carbon concentration during 
a Phaeocystis-dominated bloom at an Antarctic coastal site. Polar Biology 12: 387-395.

DENMAN KL, G BRASSEUR, A CHIDTHAISONG, P CIAIS, PM COX et al. (2007) Couplings between changes in the climate system and biogeochemistry. In: Solomon S, D Qin, M Manning, Z Chen, M Marquis, et al. (eds) Climate change 2007: The physical science basis. Contribution of Working Group I to the Fourth Assessment Report of the Intergovernmental Panel on Climate Change: 499-588. Cambridge University Press, Cambridge, UK.

DIEZ B, C PEDROS-ALIO \& R MASSANA (2001) Study of genetic diversity of photosynthetic picoeukaryotes in different oceanic regions by small-subunit rRNA gene cloning and sequencing. Applied and Environmental Microbiology 67: 2932-2941.

DOOLITTLE DF, WKW LI \& AM WOOD (2008) Wintertime abundance of picoplankton in the Atlantic sector of the Southern Ocean. Nova Hedwigia 133: 147-160.

DORAN PT, JC PRISCU, WB LYONS, JE WALSH, AG FOUNTAIN et al. (2002) Antarctic climate cooling and terrestrial ecosystem response. Nature 415: 517-520.

FALKOWSKI PG, RT BARBER \& V SMETACEK (1998) Biogeochemical controls and feedbacks on ocean primary production. Science 281: 200-207.

FIALA M, EE KOPCZYNSKA, C JEANDEL, L ORIOL \& G VETION (1998) Seasonal and interannual variability of size-fractionated phytoplankton biomass and community structure at station Kerfix, off the Kerguelen Islands, Antarctica. Journal of Plankton Research 20: 1341-1356.

FIELD CB, MJ BEHRENFELD, JT RANDERSON \& PG FALKOWSKI (1998) Primary production of the biosphere: Integrating terrestrial and oceanic components. Science 281: 237-240.

FRYXELL GA \& GA KENDRICK (1988) Austral spring microalgae across the Weddell Sea ice edge: Spatial relationships found along a northward transect during AMERIEZ 83. Deep Sea Research Part A. Oceanographic Research Papers 35:1-20.

GAST RJ, MR DENNETT \& DA CARON (2004) Characterization of protistan assemblages in the Ross Sea, Antarctica, by denaturing gradient gel electrophoresis. Applied and Environmental Microbiology 70: 2028-2037.

HOLLAND MM \& CM BITZ (2003) Polar amplification of climate change in coupled models. Climate Dynamics 21: 221-232.

HOLLIBAUGH J, C LOVEJOY \& A MURRAY (2007) Microbiology in polar oceans. Oceanography 20: 140-145.

HUNTLEY ME, MD LÓPEZ \& DM KARL (1991) Top predators in the Southern Ocean: A major leak in the biological pump. Science 253: 64-66.

KANG S \& S LEE (1993) Antarctic phytoplankton assemblage in the western Bransfield Strait region, February 1993: Composition, biomass, and mesoscale distributions. Marine Ecology Progress Series 129: 253-267.

LEPERE C, M DEMURA, M KAWACHI, S ROMAC, I PROBERT \& D VAULOT (2011) Whole Genome Amplification (WGA) of marine photosynthetic eukaryote populations. FEMS Microbiology Ecology 76: 513-523.

LÓPEZ-GARCÍA P, F RODRÍGUEZ-VARELA, C PEDROSALIO \& D MOREIRA (2001a) Unexpected diversity of small eukaryotes in deep-sea Antarctic plankton. Nature 409: 603-607.

LOPEZ-GARCIA P, A LOPEZ-LOPEZ, D MOREIRA \& F RODRÍGUEZ-VARELA (2001b) Diversity of free-living prokaryotes from a deep-sea site at the Antarctic Polar Front. FEMS Microbiology Ecology 36: 193-202.

LOVEJOY C, EC CARMACK, L LEGENDRE \& NM PRICE (2002) Water column interleaving: A new physical mechanism determining protist communities and bacterial states. Limnology and Oceanography 47: 1819-1831.

MANGANELLI M, F MALFATTI, TJ SAMO, BG MITCHELL, H WANG \& F AZAM (2009) Major role of microbes in carbon fluxes during Austral winter in the Southern Drake Passage. PLoS ONE 4: e6941.

MASSANA R (2011) Eukaryotic picoplankton in surface oceans. Annual Review of Microbiology 65: 91-110.

MONTES-HUGO M, SC DONEY, HW DUCKLOW, W FRASER, D MARTINSON, SE STAMMERJOHN \& O SCHOFIELD (2009) Recent changes in phytoplankton communities associated with rapid regional climate change along the Western Antarctic Peninsula. Science 323: 1470-1473.

MURA MP, MP SATTA \& S AGUSTÍ (1995) Water-mass influences on summer Antarctic phytoplankton biomass and community structure. Polar Biology 15: 15-20.

NEALE PJ, JJ FRITZ \& RF DAVIS (1991) Effects of UV on photosynthesis of Antarctic phytoplankton: Models and their application to coastal and pelagic assemblages. Revista Chilena de Historia Natural 74: 283-292.

NICOL S, A WORBY \& R LEAPER (2008) Changes in the Antarctic sea ice ecosystem: Potential effects on krill and baleen whales. Marine and Freshwater Research 59: 361-382

PIQUET AM-T, H BOLHUIS, AT DAVISON, PG THOMSON \& AGJ BUMA (2008) Diversity and dynamics of Antarctic marine microbial eukaryotes under manipulated environmental UV radiation. FEMS Microbiology Ecology 66: 352-36.

RIAUX-GOBIN C, M POULIN, R PRODON \& $\mathrm{P}$ TREGUER (2003) Land fast ice microalgal and phytoplanktonic communities (Adélie Land, Antarctica) in relation to environmental factors during ice break-up. Antarctic Science 15: 353-364.

RODRÍGUEZ J, F JIMÉNEZ-GÓMEZ, JM BLANCO \& FL FIGUEROA (2002) Physical gradients and spatial variability of the size structure and composition of phytoplankton in the Gerlache Strait (Antarctica). Deep Sea Research Part II: Topical Studies in Oceanography 49: 693-706.

ROGERS AD (2007) Evolution and biodiversity of Antarctic organisms: A molecular perspective. Philosophical Transactions of the Royal Society of London B 362: 2191-2214.

SAVAGE RE (1930) The influence of Phaeocystis on the migration of herring. Fishery Investigations MAFF London Series 2 (UK) 12: 5-14.

SIEBURTH J, V SMETACEK \& J LENZ (1978) Pelagic ecosystem structure: Heterotrophic compartments of the plankton and their relationship to plankton size fractions. Limnology and Oceanography 23: 1256-1263.

SIEBURTH JMcN (1960) Acrylic acid, an 'antibiotic' principle in Phaeocystis blooms in Antarctic waters. Science 132: 676-677. 
SIMMONDS I \& X WU (1993) Cyclone behaviour response to changes in winter southern hemisphere sea-ice concentration. Quarterly Journal of the Royal Meteorological Society 119: 1121-1148.

SMETACEK V \& S NICOL (2005) Polar ocean ecosystems in a changing world. Nature 437: 362 368.

SMETACEK V, P ASSMY \& J HENJES (2004) The role of grazing in structuring Southern Ocean pelagic ecosystems and biogeochemical cycles. Antarctic Science 16: 541-558.

SOLOMON S, D QIN, M MANNING, Z CHEN, M MARQUIS, K AVERYT, M TIGNOR \& H MILLER (eds) (2007) Contribution of Working Group I to the Fourth Assessment Report of the Intergovernmental Panel on Climate Change, 2007. Cambridge University Press, Cambridge, UK.

STOECKER DK, M PUTT \& T MOISAN (1995) Nanoand microplankton dynamics during the spring Phaeocystis sp. bloom in McMurdo Sound, Antarctica. Journal of the Marine Biological Association of the United Kingdom 75: 815-832.

TURNER J, SR COLOWELL, GJ MARSHALL, TA LACHLAN-COPE, AM CARLETON et al. (2005) Antarctic climate change during the last 50 years. International Journal of Climatology 25: 279-294.
WEBER LH \& SZ El-SAYED (1987) Contributions of the net, nano- and picoplankton to the phytoplankton standing crop and primary productivity in the Southern Ocean. Journal of Plankton Research 9: 973-994.

WRIGHT S, D THOMAS, H MARCHANT, H HIGGINS, M MACKEY et al. (1996) Analysis of phytoplankton of the Australian sector of the Southern Ocean: Comparisons of microscopy and size frequency data with interpretations of pigment HPLC data using the "CHEMTAX" matrix factorisation program. Marine Ecology Progress Series 144: 285-298.

WRIGHT SW, A ISHIKAWA, HJ MARCHANT, AT DAVIDSON, RL ENDEN \& GV NASH (2009) Composition and significance of picophytoplankton in Antarctic waters. Polar Biology 32: 797-808.

TORRES-ZAMBRANO G \& ME TAPIA (1998) Distribución del fitoplancton en el Estrecho Bransfield, Bahía Chile y Paso Drake, durante el verano austral 1998 (Antártida). Acta Antártica Ecuatoriana 4: 101-114.

ZEHR JP, SR BENCH, BJ CARTER, I HEWSON, F NIAZI et al. (2008) Globally distributed uncultivated oceanic N2-fixing cyanobacteria lack oxygenic photosystem II. Science 322: 1110-1112. 
